\title{
Prólogo \\ Kóot, una nueva fuente de conocimiento
}

Ha nacido una nueva revista; pero no solamente una más, porque en su género, por ahora, es única en nuestro país. Esta trae bajo el brazo la ciencia museológica vista desde la perspectiva científica e institucional de la Universidad Tecnológica de El Salvador.

Como rector de esta casa de estudios, es un motivo de gran satisfacción para mí presentar el primer número de nuestra revista de museología Kóot, palabra en verdad difícil de pronunciar, pero que se ha extraído de nuestro idioma ancestral que aún late en algunos lugares de estas tierras.

Aunque su contenido será principalmente de museología, también enfocará temas concretos del amplio espectrum de la antropología, abordando temas que abarcarán la arqueología, la historia y la lingüística y otros aspectos de interés científico relacionados.

Quizá usted, estimado lector, se pregunte qué significa kóot. Su traducción es, ni más ni menos que "águila", en náhuat, el símbolo por excelencia de nuestra universidad.

La Utec agradece de una manera muy especial a los generadores de esta nueva fuente de transmisión del conocimiento, cuyo principal promotor es el Museo Universitario de Antropología, así como a su editor, a los escritores, los redactores invitados, los diseñadores y los ilustradores y a todos aquellos que con su colaboración hacen posible tener la primera Kóot en nuestras manos.

Publicaciones como esta son tan necesarias en nuestro medio así como en Centroamérica, para el abordaje del estudio de nuestra identidad desde sus orígenes, llegando con la investigación hasta lo contemporáneo.

Tenemos la esperanza de que este esfuerzo compartido sea del interés de los entendidos en estas materias y que sirva para motivar a otros profesionales y estudiantes, para que encuentren respuestas a sus preguntas sobre nuestro pasado y presente, tal vez mediante las líneas de esta publicación.

Dr. José Mauricio Loucel

Rector 


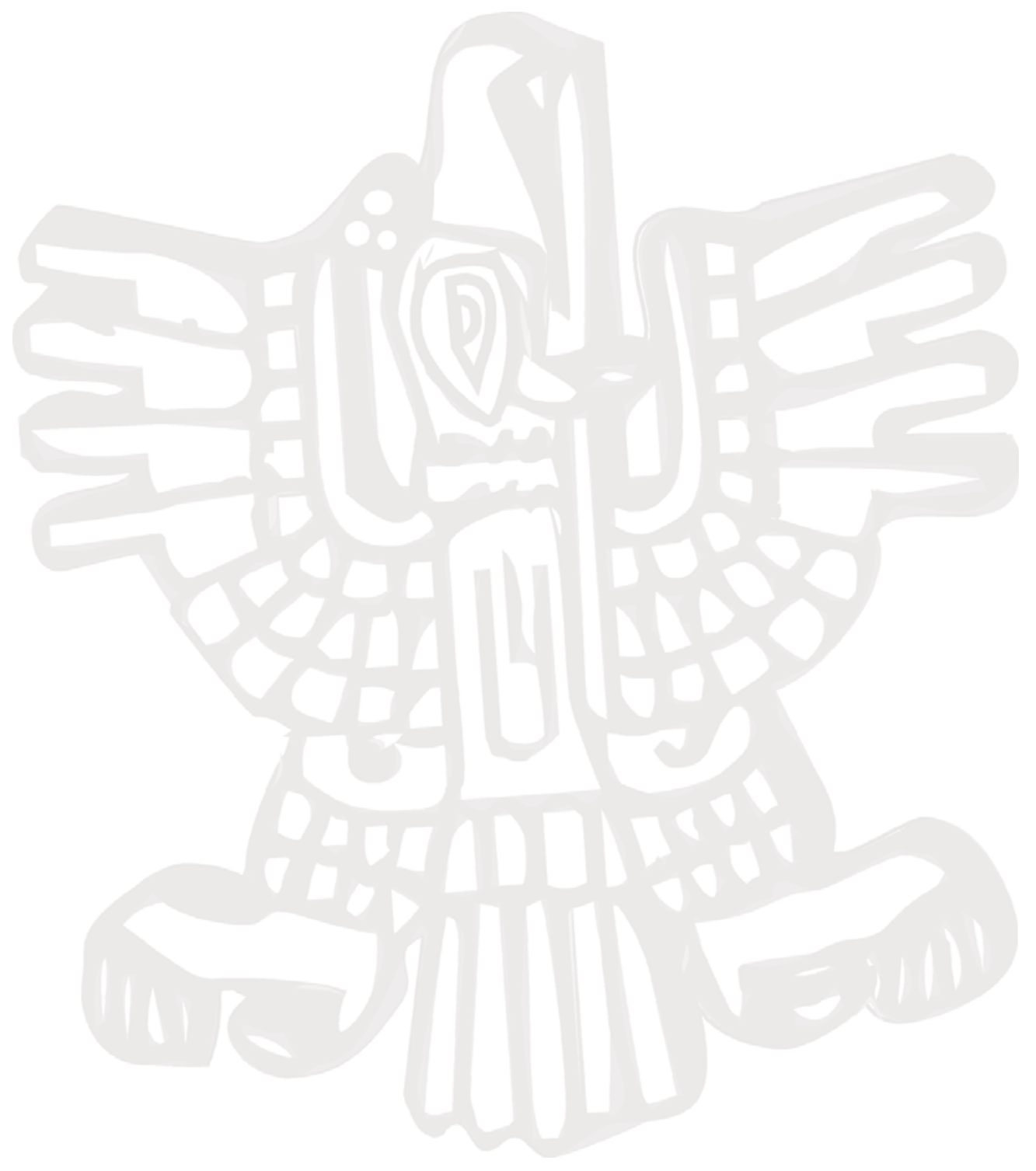

